\title{
The varieties of the modern Udmurt language
}

The present paper classifies and describes the main linguistic varieties of the modern Udmurt language across the community of speakers and gives some examples of their linguistic specificities. The study takes a particular look at the vernacular and standard language varieties. The first section defines the main terms and notions that are employed in the article. In the second part, the sources of the study including the empirical data are briefly described. The third section is devoted to the description of the linguistic features of the main varieties. The last part consists of a conclusion.

1. Introduction

2. Research material

3. Language varieties and general styles

3.1. Vernacular varieties

3.1.1. Local vernaculars

3.1.2. Cross-local vernaculars

3.2. The standard variety
3.2.1. Carefully composed texts

3.2.2. Texts produced by

mass-media sources

3.2.3. Spoken language

approximated to

standard language

4. Conclusions

\section{Introduction}

Languages are constantly in a state of change and, in the contemporary environment, many of them face serious challenges to survival. To understand language change, maintenance and loss, we must seek further knowledge regarding the functioning of languages in modern societies. This study of language variation in Udmurt offers a contribution to such an investigation.

Today there are a vast number of studies on dialect variation in the Udmurt language. Since not all local language varieties have been studied thus far, this remains a leading focus of research in traditional linguistics. Most of the modern descriptive studies are made based on material representing the standard form or "high language", particularly literary texts. There are also a very few surveys of mass-media language style. Furthermore, one rarely comes across studies examining the usage and vari- 
ation of these language forms, cases of shifting from one style or dialect to another, etc. When describing Udmurt, it is clear that some grammatical constructions or words appear only in the "high language" and exist mainly in the written form. At the same time, real-world colloquial language forms no longer represent pure dialects, but there is a rich mixture of dialect and standard forms, and an enormous number of loans from Russian, including code mixing. The investigation of language varieties is an especially timely enterprise, since language varieties of Udmurt differ in a great sense in linguistic expression, communicative functions and social significance. A similar linguistic situation can be observed among other minorities with a similar sociocultural environment and linguistic tradition, in particular among the minority Finno-Ugrian languages. Most of the speakers of these languages are bilinguals under the domination of the Russian language; most of them have fairly recently formed literary standards and use a dialect as their vernacular variety, while the standard language exists only in written form. Most of these languages are in danger of disappearing.

The chief objective of the present paper is to define the main social language varieties used by the Udmurts in everyday life, and to describe the main linguistic features of these varieties. The study also tries to answer questions such as what kind of language the Udmurt people use in realworld contexts and what kind of conditions influence such language use.

Some linguists call any kind of language variety a dialect and define it as "any variety of a language which is shared by a group of speakers" (Wolfram \& Schilling-Estes 1998: 2; Myers-Scotton 2006, etc.). Other researchers call such variation a language difference, language variety or language variation; sometimes it can be also defined as a style (Patrick 2011). Thus, they distinguish between, for example, standard and vernacular dialects. However, in the present study, I use the term dialect in its traditional sense and refer to a language variety of a group from a concrete linguistic area. In the paper, I define standard and vernacular as two main language varieties and call them language varieties or languages. These language varieties can be investigated from the perspective of stylistics, domains of language usage or registers and forms used, e. g. written and spoken forms. The present study focuses mostly on the stylistic aspect and language form, namely what kind of general styles appear in standard and vernacular varieties, in oral and written forms, and what linguistic specificities they have. 
The present article is a part of a more comprehensive research venture on language change and maintenance of the Udmurt language being carried out in the framework of the research project "Empowerment and revitalization trends among the linguistic minorities in the European Union and the Russian Federation" (University of Helsinki, Finno-Ugrian languages).

All examples are given according to the traditional transcription (e. g. as presented by Kel'makov \& Hännikäinen 1999: 13).

\section{Research material}

The study is based on an analysis of written and spoken language material. Some examples of the vernacular variety come from data collected by the author during fieldwork in the Udmurt Republic in March 2011. Most of the dialectal text collections that exist today represent narrations by elderly people. Older informants are traditionally considered a source capable of reproducing the "purest" dialect features. However, this kind of material alone does not accurately reflect real language use, because also younger generations use the language. Furthermore, the genre of narratives demands specific linguistic and discourse structures, and differs, for example, from the structure of dialogues. Therefore, the purpose of this study is primarily to define the properties of "living" or real spoken language.

Examples from the magazine Invožo and the newspaper Udmurt Duńne, and transcripts from the television and radio channel Moja Udmurtia illustrate the standard language variety.

\section{Language varieties and general styles}

The most significant linguistic difference may be observed between standard and vernacular varieties of the modern Udmurt language. This can be explained by diglossia between standard and vernacular forms. Such diglossia is connected with the written and spoken traditions of the language. Such dimensions in Udmurt are conditioned by the historical maturation of these forms. A standard variety for Udmurt arose only a short time ago, and in fact, this appeared as a written form, which was not finally established until the beginning of the 2oth century. Even today, the standard variety exists mainly in written form. Since the distribution and usage of the standard form have been and continue to be limited, it significantly 
differs from spoken styles, and knowledge of it among the Udmurts varies a great deal.

Furthermore, the empirical data demonstrates that the vernacular spoken nowadays by the Udmurts may be used in two main dimensions which differ linguistically from one another: as a local or dialect vernacular and as a cross-local vernacular. In the former case, features of a particular dialect appear, while in the latter case, features of mixed dialect and standard forms are typical. The standard form varies as well. An analysis of existing written material leads to the conclusion that carefully composed texts, including literary works, can be distinguished from the texts produced by the mass media. Of course, different genres require different styles or different language, but Udmurt has a recently established literary tradition, and knowledge of the language varies from one author to another, while the quality of written texts also varies greatly. Therefore, from this perspective the main factor in classifying a language variety or style classification is not the text genre, but the conditions under which the text was produced. In particular, when an author produces his or her own text, he or she has more linguistic freedom, but in mass-media discourse, a writer is influenced by linguistic clichés and models, especially if using original sources in Russian. Finally, the standard language remains an acquired language, not a native one, and therefore it is more difficult to use it in a spoken form. Therefore, spoken standard language also has its own linguistic specificities.

1. Vernacular variety
a. local vernaculars
b. cross-local vernaculars

2. Standard variety
a. carefully composed texts
b. texts produced by mass-media sources
c. spoken language that approximates the standard form

This classification may be seen as universal, applying also to languages whose situation is similar to that of Udmurt, i. e. minority languages spoken by bilingual populations with more recent literary traditions. In particular, it can be applied to Finno-Ugrian minority languages from Russia and Europe. 


\section{I. Vernacular varieties}

\section{I.I. Local vernaculars}

Most vernacular varieties are based on the dialects acquired by the Udmurts as a native language. Udmurt dialects show great variation, conditioned by contact-induced change and internal developments. In particular, the Northern dialects have been influenced by Russian from an earlier date than Southern dialects. The Southern dialects were formed under the influence of Tatar. The Middle dialects combine the features of the Northern and the Southern dialects but also have their own peculiarities. The Periphery dialects are spoken by Udmurts living in the diaspora outside of the Udmurt Republic, and vary according to the languages with which they are in contact. The Besserman language that is spoken in some villages in Northern and to a lesser degree in Middle Udmurtia is also treated as an Udmurt dialect, although the Bessermans have recently been recognized as an independent ethnicity with their own language.

The dialects exhibit an extremely rich linguistic diversity, especially on the lexical level. For instance, according to the Atlas of Udmurt Dialects (Nasibul'l'in 2009: 205), the expression ladybug is encoded using 124 lexemes across the area in which the language is spoken. The dialects vary at all levels. On the phonetic level, some Periphery dialects possess more vowels than other dialects, but some of them lack affricates common in other dialects. There is quite a large variation in the lexicon, e.g. Southern ukśo and Northern, Mid. końdon 'money'; Southern kisi and Northern ̌̌́ep, Mid. korman 'pocket'; Southern iźini and Northern, Mid. kelini 'to sleep'; Southern kirin and Mid. pedlon 'outside', etc. Different suffixes can mark the same grammatical categories across different dialects. For example, the plural accusative is expressed by the marker - $i z$ in the Southern dialects as in (1a), while in the Middle and North dialects the variant -t $i$ is used, cf. (1b).
(1) a. aร̌šri-śko
korka-os-iz
b. $a \breve{z} 3{ }^{2} i-s ́ k o$ korka-os-ti see-PRS-1SG house-PL-ACC 'I see houses.' 
Probably the most common variation in the morphology involves phonetic nuances in suffixes, e. g. usage of different vowels, and other modifications. For example, in the Southern and Northern dialects, as well as in the standard language, the present tense marker of some verbs in the 1st and 2nd persons is -(i)śko- (as in 2a), but in the Middle dialects it is common to use the short form $-k o-(2 b)$.

\section{(2) a. mini-śko-d \\ b. min-ko-d go-PRS-2PL 'You go.'}

The dialects also differ on the level of morphosyntax. They may use different morphosyntactic constructions, e.g. in the Southern variant the synthetic method is employed for the negative form of the second preterite, as in (3a), while in the Northern variant an analytic method is used, cf. (3b).

(3) a. so vera-mte-jez

(s)he say-2PRT.NEG-3SG

b. so evel vera- $m$

(s)he NEG say-2PRT

'Apparently (s)he didn't say'.

The Udmurt dialects are currently undergoing changes and taking on new features. They are particularly influenced by the standard language, while each particular small community shows different processes of change caused e. g. by interference from Russian or other motivations. Thus, the language of younger speakers in local communities may represent different features than that of the older generation. As a rule, the specific phonetic qualities of a dialect yield more easily to changes than morphological qualities. For example, the Middle dialect shows a distinctive phonetic phenomenon of affrication (the presence of extra affricates in medial and

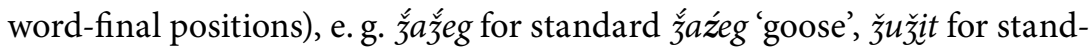

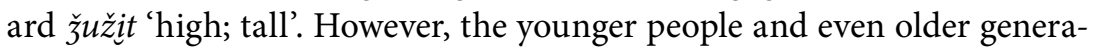
tions among my informants from the village of Porozovo, under the influence of standard forms, use the common or standard variant without an additional affricate in these cases, while in the vernacular of their grandparents the dialectal variant remains sporadically attested. However, all 
generations in this village continue to regularly use the short variant of the present tense marker $k o$, while the standard long form appears more rarely. My fieldwork data also demonstrates that some people in Porozovo use the lexeme kil for 'tongue (body part)', but when they are speaking of language as an abstract notion, they use the Russian loan jazik.

In example (4), I (indicated by A) speak with a 24 -year-old male informant (B) from Porozovo village about his military service. He studied Udmurt in school until the gth year and has an intermediate or even poor knowledge of the standard language.

(4) A. iževsk-in se keña voź-i-zi?

Iževsk-INE then how.much keep-1PRT-3PL

'How long did they keep you in Izhevsk?'

B. ižesk-in mi-lemdis voź-i-zi sbor-in kuiń nunal

Iževsk-INE 1PL-ACC keep-1PRT-3PL muster-INE three day

kin-e kičćc nuni šusa. obrazovaní-z-es

who-ACC where bring.INF CONJ education-3-ACC.PL

jua-zi, fižič́eski podgotovlennost-ez esker-i-zi

ask-1PRT.3PL physical readiness-ACC exam-1PRT-3PL

$\boldsymbol{i}$ oźi raspredelit kar-i-zi, kin-e kiḉći nuni.

and this.way assign.INF do-1PRT-3PL who-ACC where bring.INF

'They kept us mustered for three days in Izhevsk to assign us places. They asked about education; they examined physical

readiness, and this way they assigned who to send where.'

A. to jest' aćid ton ud-a vibratti-śk-i,

that.it yourself 2SG NEG.PRS.2-INTR choose-PRS-SG

kičč́i min-ono?

where go-PRTC

'That means you don't choose where to go yourself?'

B. vibratti-śko-d, no, naprimer, pot-e val

choose-PRS-2SG but for.example go.out-PRS.3SG AUX.1PRT

specnaz-e, no min-am rost-e ug

special.forces-ILL but 1SG-GEN height-1SG NEG.PRS.3

okm-i val. meńše .... śu tamiston-leś iči,

suffice-sg AUX.1PRT few.CMP ..... hundred eighty-ABL few

pe, adami luni evel kule.

they.say human be.INF NEG need

'You do choose, but, for example, I wanted to go to a special

forces unit, but I did not have enough height. A person [human]

should be no shorter than ... one hundred eighty, they say.' 

A. a tin-ad kičce rost-ed?
and 2SG-GEN what height-2SG
'And what is your height?'

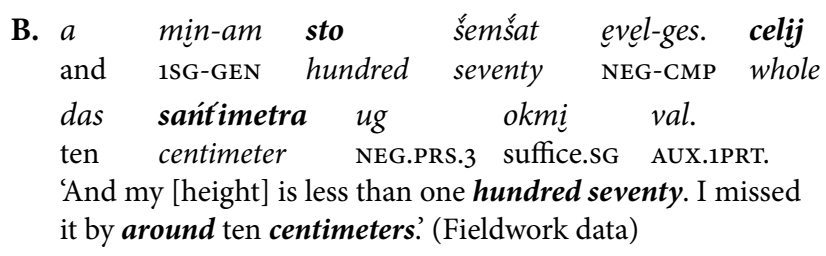

In this example, the informant exhibits typical dialect features, e.g. dialectal words such as iči 'few' versus standard ězit; okmini 'to suffice' versus standard tirmini; se 'than' versus standard sobere. He drops the vowel $-i$ in verbs, cf. dial. nuni versus standard nuini 'to bring'. The informant borrows many Russian words (marked in bold in the example), and mixes Russian and Udmurt morphosyntax, e.g. the construction in meńše .... śu tamiston-leś iči ' few ... few[er] than one hundred eighty', where the speaker mixes the Udmurt construction noun-ABL + few with the Russian pattern few + noun. The informant uses Udmurt words when expressing simple numerals, e.g. kuin nunal 'three days', das sańtimetra 'ten centimeters'; but he expresses compound numerals in Russian, e. g. sto šemšat evel-ges 'less than one hundred seventy'. In this example, the numeral is phonetically adapted to the Udmurt language, namely in the word 'seventy', where he replaces the Russian palatal sibilant $s$ with the alveolopalatal sibilant $\dot{s}$, which is considered a typical feature of the Udmurt accent in Russian. However, during the interview the informant also uses śs correctly when borrowing from Russian. The informant also knows the Udmurt names of compound numerals. Since the interview was to some degree an official situation (the voice recorder was switched on in front of him), he consciously tried to express compound numerals in Udmurt, cf. śu tamiston-leś ići 'less than one hundred eighty', but he had to pause to remember them. However later the informant unconsciously uses compound numerals in Russia, cf. sto šemśat evel-ges 'less than one hundred seventy'. In the same way, at the beginning of the interview he attempted to speak of the month of October in Udmurt, but erred and said šurkinmon, which means 'November'.

Since the standard language combines features of the Northern and the Southern dialects, those Udmurts who have studied the language in school and who read in Udmurt are able to understand other dialects quite eas- 
ily. However, the differences between the varieties remain large, especially between dialects spoken in Tatarstan and Baškortostan.

The local vernacular is acquired as a mother tongue and transmitted orally within the family. Such speech dominates in local communities, e. g. among people from the same village and among family members. It may be the only Udmurt language style that non-mobile representatives of such communities possess. However, it may also count as one of multiple Udmurt styles in a speaker's linguistic repertoire. People from urban communities who have Udmurt-speaking social circles, as a rule, keep this style in their networks with relatives and fellow villagers, while in other Udmurt networks other styles can be applied, e.g. a cross-local style. If a person was born in the city and his or her parents hail from different dialect areas, then he or she probably acquires dialect features from the parent or grandparent who played a greater role in his or her language acquisition.

\section{I.2. Cross-local vernaculars}

The colloquial language that is used among the Udmurts from different dialect groups has not yet been the subject of investigation. Except in writing, the Udmurt intelligentsia uses a colloquial language among themselves; young people who move to the city for work or study adopt new conversation styles to communicate with each other. Cross-local vernaculars appear primarily in urban communities in Udmurt-speaking networks where conversation in Udmurt is possible. The best example comes from the faculty of Udmurt philology at the university, where young people from different places and representing different dialects come together each year to study. Students from different dialect backgrounds may initially communicate with each other in their native dialects. However, such conversations may be uncomfortable because they involve extra mental effort. Furthermore, students may also become the target of ridicule because they use different linguistic forms from other speakers. These factors may cause them to switch into Russian, especially when communicating in a non-Udmurt environment.

Within the faculty of Udmurt philology, after some time has passed, everyone is eventually able to communicate in some kind of common language and no one is mocked any more. The students tend to refer to this colloquial form as the "literary language", but this spoken language differs a great deal from written standard language. These students, as profes- 
sional users of the Udmurt language, are able to master and reproduce standard forms and easily manipulate different styles, e. g. write articles and scientific texts, give a speech, etc. However, this requires deliberate mental effort and standard language never appears as a spontaneous spoken language. As soon as it appears as non-controlled speech, it is no longer the "literary language" but a language that approximates the standard variety (see section 3.2.3.).

The cross-local colloquial style, on the other hand, is a mix of local vernaculars with the standard style and Russian. Linguistic features here are conditioned by the setting of the conversation, including the linguistic background of the interlocutors. For example, I am a native speaker of a dialect that uses the short variant of the present tense marker $k o$, the plural accusative form $t i$, and the lexemes kondon 'money', kelini 'to sleep', pedlon 'outside', etc. As someone with a good knowledge of the standard language, I am familiar with the standard and dialect variants of these words and grammatical forms. I have noticed that if my interlocutor regularly uses the long variant of the present tense marker, I unconsciously emulate him and also use this form, as well as the lexemes ukśo 'money', izini 'to sleep', kirin 'outside', etc. Nonetheless, they do not appear regularly and alternate with the forms of my dialect. On the other hand, if my interlocutor is a native speaker of a dialect with the long form of the present tense marker -śko-, he or she is less motivated to use the short form, since it is not recognized in the standard language and therefore has a restricted distribution. Similarly, he or she will probably prefer not to use nonnative dialect words, e. g. pedlon 'outside', or use it only to make a joke and imitate the dialect style of an interlocutor. However, specific dialect features that are not known in the standard language can pass into the language repertoire of speakers from a different dialect area if they have a close relationship, e. g. among friends, lovers or roommates.

Another significant feature of the cross-local vernacular is an abundance of borrowings from Russian and often language switching and language mixing. While cross-dialect communication in most cases happens in an urban environment and could also appear in formal situations (conversation with a teacher, literary figure, etc.), it involves such expressions and notions that are not often used in conversation between members of a local community or families. Most of these expressions and notions have an Udmurt variant only in the standard style or do not have an Udmurt equivalent at all (e.g. expressions that belong to Russian slang). When 
speaking with family, friends, acquaintances or higher-ranking people, one would prefer to use the expressions meroprijatije 'an event (Rus.)' and dokument-jos [document-PL (Rus.)] 'documents', but in texts she or he would write užrad 'event (Udm.)', užkagaz-jos [document-PL (Udm.)]. In non-official situations it is possible to use the Russian slang expression prikolno 'cool, funny', which can be expressed in Udmurt by the neutral term tunsiko [interesting (Udm.)] or by words tumošo [funny (Udm.)] and śeremes [funny (Udm.)] 'funny, amusing'; however Udmurt terms thus do not have the same emotional and stylistic character.

It should be pointed out that all of the vernacular styles described above exist mostly in spoken form, but they may appear in written form as well. They may be used in personal letters and notes, on the internet (in social networks, Udmurt forums, blogs or e-mails), in SMS messages, etc.

\subsection{The standard variety}

Unlike many other Finno-Ugrian languages, the Udmurt language has only one literary language. The birth of the literary language is thought to date back to 1775, when the first grammar was written by the missionary Pucek Grigorovič. The late 18th century and the 19th century saw the appearance of further dialect-based grammar descriptions (Mogil'in 1786, Wiedemann 1851, Aminoff 1896), and translations were made of the Gospel and other religious literature. Nevertheless, the intensive process of creating the literary language was not started until the 1930s. Until the end of the 19th century, the language existed only in spoken form as dialect vernaculars. The language was used only in rural and traditional life until the beginning of the 1920 .

The function of a standard language is different from that of a vernacular one - it serves formal domains of language use, including writing. Since the Udmurt language had not been used in this domain, the Udmurt intelligentsia had to create a new language style that was, above all, appropriate for writing. According to G. Sampson, "official” versions of languages in all parts of the world show isomorphism and have been heavily remodeled under European influence, e. g. formal Indonesian shares many features of European languages, but colloquial Riau Indonesian does not (2009: 15-16). Something similar has happened with the Udmurt standard language, as it was modeled after the Russian standard language. Thus, a vast amount of new borrowed expressions, notions, cultural clichés 
and grammatical constructions that were adopted into Udmurt formed the basis of the Udmurt standard language. Vahrušev assumes that purist tendencies that were in place among the Udmurt intelligentsia of the 1920 f favoured the adoption of a large number of grammatical and expressional calques from Russian. As a result, the new style of the Udmurt language - the standard style - took on a completely artificial character. However, subsequent decades saw a counterweight, as the purist tendency retreated and original Russian loans were favoured between the 1950 s and the 1980s (Vahrušev 1975). Indeed, as Kreindler (1989) notes, the language policy of the Soviet Union after the 1950s did not allow creation of neologisms but preferred to borrow or "enrich" minority languages with loans from Russian. Thus, before perestroika standard Udmurt (especially the language that was used at the official level and in education and sciences) contained many Russian loans. This language was taught in schools and widely transmitted by mass media (mostly newspapers and radio). This type of standard language became well known to the speakers.

The next wave of language standardization or remodeling appeared in the period following perestroika. Sociocultural changes and the fall of the embargo on language purism brought changes to the language. In particular, the same purist attitudes arose anew at this time and have continued until the present day. A vast amount of new terms appear every day that vary from author to author, from individual speaker to speaker, and from publication to publication. This process is especially current in mass media, since many readers and spectators complain of misunderstanding of new words. There are also many discussions among the Udmurt intellectuals about language strategies. In particular, there are two tendencies of language ideology today: those who want to translate everything into Udmurt, and those who follow the soviet traditions and insist on using Russian terms that were already established and used during the long soviet period, e.g. for the names of the days, months and holidays.

Earlier inventions of the standard language include such lexemes as veros 'a story; novel', kilbur 'a poem', kilburći 'a poet, a poetess'; conventionalization of the conjunction mali ke šu-ono [why if say-PRTC/NES] 'because'; a new function of the adverbial (see below) and functional expansion of the genitive and other case markers. Today these are used and recognized by most Udmurts or at least by those who have learned the standard language in school. Among recently coined terms are emjaśkońni 'hospital', užbergatiś 'businessman', etc. Some of them have already be- 
come popular and are understandable at least to the intelligentsia. However, many of them exist only in listings of neologisms, created by the terminological committee e.g. viźužaś 'intelligentsia', uźmag 'paradise' (Bul'l'eten' 2008).

There is great interference from dialects into the standard language as well. When the Udmurt intelligentsia began to standardize the language in the beginning of the 2oth century, some of them proposed the Northern dialect as a basis for the standard form, while others proposed the Southern variant. In the end, however, diverse lexical, morphological and morphosyntactic variation in the standard language has been accepted as a compromise between supporters of the Southern and Northern dialects (Vahrušev 1975: 52; Luutonen 2000: 28). For instance, for the terms money and pocket, lexemes from both dialects are accepted as standard. Both plural accusative markers and both morphosyntactic patterns of negation in the second preterite can be used in the literary language. However, the short variant of the present tense marker $k o$ and certain lexemes, e.g. the Middle variant pedlon 'outside' and korman 'pocket', are not permitted in standard-language discourse or in written form. The norms of the standard language have nonetheless not yet been well established. In most cases, it is possible to trace the authors of literary texts to a particular dialect, because the producers of texts refer habitually to forms in their dialect, even when they try to enrich their texts by employing different dialect variants.

The Udmurt standard language is an acquired literary style, not a native language for Udmurts. The standard form is spread by teaching in the schools, the mass media and literary works. Through these channels, the artificial standard language has reached rural Udmurt communities. It becomes natural to those who deal often with the standard language - those who read and write frequently in Udmurt and deal with the language on a professional level. Therefore, knowledge of the standard language varies among the speakers. On one hand, those with a good command of the standard language can produce and use standard forms and most neologisms in their language repertoire. On the other hand, speakers with a low level of knowledge can recognize standard forms such as the Udmurt names of days and months, expressions like mali ke šu-ono 'because', and accept expanded usage of case markers, but they do not employ them in their speech. For example, the informant in (5) was unable to refer to the month of October in Udmurt. Finally, some people may consider the standard style to be a foreign language. 
The standard language can also vary. As mentioned above, the linguistic features of standard varieties depend primarily on the conditions in which they are utilized. In particular, carefully composed texts differ from news texts as well as from spoken standard forms.

\subsection{Carefully composed texts}

A specific property of carefully composed texts is that writers are supposed to pay more attention to the language they employ and they have greater linguistic freedom. They are also free to choose a strategy when composing the text. That is, if the author upholds purist tendencies, he or she may use udmurtized words and patterns, but if not, Russian loans may be employed. The quality of the language in scientific and other published texts depends on the skills of the writer in the language. While some authors are able to write in beautiful prose about any topic, e. g. economics or chemistry, others end up producing artificial language forms. The tendency to use udmurtized words, if the writer lacks a good command of the language, does not help to make the text aesthetically pleasing, but rather the opposite. The text in (5) is a passage from a scientific article. The author explains in good language what an epic is. The author is an Udmurt linguist who is used to writing in the language and who has good standard language skills.

(5) epos - so, tunne kil-in epic it today language-INs vera-sa, bides kalik-len ogaźeja-m say-GER whole nation-GEN unite-PRTC

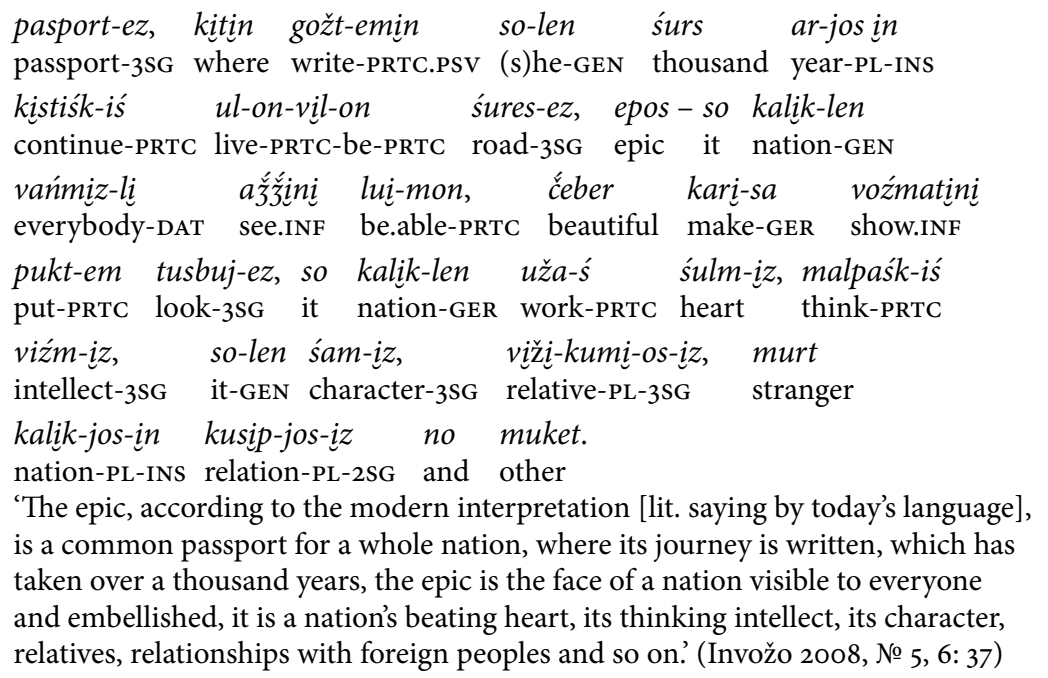


Example (5) is a complex text. However, there are not many Russian loans. One borrowed construction is present - a dependent clause with a conjunction (cf. kitin gožt-emin... 'where it is written...') - but this seems quite natural in the scientific genre and in such a complex text. The fragment contains many participial constructions, cf. ažžini lui-mon 'visible (lit. that which is possible to see)', kistiśk-iś śures-ez 'lit. lasting road', etc. This is the Udmurt means of incorporating several relative clauses into one, which helps to avoid using borrowed patterns with conjunctions. There are also a number of metaphors, e. g. epos so kalik-len pasportez, tusbuj-ez, sulm-iz'the epic is a passport, the look, the heart of a nation', etc. I have noticed that Udmurt texts, even ones written in this scientific style, as well as texts from the mass media, employ a high number of metaphors. This may help to avoid using neologisms and Russian loans. It also seems that this metaphoric way of thinking is very typical of Udmurt traditional thinking. It is probably a matter of style that has not yet been completely remodeled under the influence of Russian and European literary traditions. Therefore, this metaphoric technique facilitates the process of reading for native speakers.

Example (6) is a passage from an essay, and it can be considered as an example of low-quality text. The author is a scientist in culture who is not used to writing and speaking in Udmurt.

(6) ućki-śko tigmet vill-e, ćakla-śko vu vad’si-ti

look-1PRS.1SG pond on-ILL guard-1PRS.1SG water surface-PRL

loba-śs ćarlan-ez, kud-iz intí-z-e vošti-tek śamen

fly-PRTC mew-ACC which-DET place-3SG-ACC change-ABs like

og.inti-ja-z porja.

one.place-INE-3SG soar.PRS.3SG

'I am looking at a pond, and watching a mew which is flying over the water, and which is soaring as if it remains motionless.' (Invožo 2004, № 10: 34)

It seems as though the author originally wrote the sentence in Russian and then translated it into Udmurt, or was thinking in Russian when writing in Udmurt. Thus, all the words are translated into Udmurt, but some cognitive strategies remain in Russian. In particular, in the construction timet vile 'at a pond', the pattern with postposition šori would be preferable. In the Russian expressions smotret' na stol 'to look at a table' and položit' $\boldsymbol{n a}$ stol 'to put on a table', the same preposition is used with non-locative and locative cases. Udmurt, however, employs two different postpositions: 
učkini žě šori 'to look at a table' and ponini క̌ş vile 'to put on a table'. Furthermore, the verb ćaklani does not fit here semantically: the verb has a semantic nuance and means 'to guard smth. or smb., to take care of smth. or smb.' which is not likely to occur in the context. This kind of style disrupts the aesthetics of the text and does not allow readers the enjoyment of reading in their native language.

Literary works can also be considered in this section. Literary texts can be seen as works of art. Here, the language forms, means of expression and choice of words have a sense greater than the information they express. Writers pay special attention to language use and spend more time choosing constructions. In the case of Udmurt, the literary tradition was completely formed in the 1920 s and 1930s. Classical Udmurt texts (especially from writers of the older generation) generally depict rural life in a realistic fashion and represent a high form of the standard language, which masterly combines loans from Russian. If loanwords are employed, they are integrated quite naturally. The syntactic constructions here remain natural. However, modern literature is dominated by descriptions of urban life and contemporary subjects that require adopting additional terms, constructions and expressions in the Udmurt language. Following post-perestroika purist traditions, some writers try to impose these new patterns into Udmurt. Writers from the older generation have greater experience and are still capable of balancing the integration of new forms with traditional ones, but beginners or inexperienced writers often go too far in creating new forms. Thus, their texts often resemble a completely artificial language that is no longer connected with the natural language, as can be seen in the text in (6). Regarding these writers, some Udmurt philologists say that they do not have "the sense of the language", that they use "dead language". This phenomenon signifies that the Udmurt language has become more endangered compared with the 1980s: new writers do not have enough experience with the language, and at the same time, they lack teachers and effective critics who would help them to develop their literary skills. Furthermore, the younger generation is influenced much more by Russian and other languages, which can have an influence on their "language sense".

Even more recently, a new wave of young writers has appeared in Udmurt literature. Some young beginning authors try to adopt natural vernacular styles in their literary texts. For instance, they use an abundant mix of Udmurt and Russian (and sometimes other foreign languages), including Russian slang expressions, dialect style, etc. as is demonstrated in (7). 
(7) kịče vań raznitsa: kẹna tinn-ỉd ares?

what EX difference how.many 2SG-DAT age

puskaj ton min-eśtim tače pinal.

let 2SG 1SG-ABL that.way young

mon todi-śko, nužna míe pozarez

ISG know-PRS.1SG need ISG.DAT very.much

ton, školńica...

2SG schoolgirl

'What is the difference: how old are you?

It doesn't matter that you're so much younger than me, I know, I need you so much

You, schoolgirl ...' (Udmurt Duńńe (Dart): 16.02.11: 5)

The text in the example approximates the vernacular style. For example, the author typically mixes Russian and Udmurt codes (the Russian loans in the text are marked in bold) and uses expressions that belong to Russian slang, cf. pozarez 'very much'. These writers are considered by conservative figures and supporters of purism to be linguistic hooligans who are demolishing literary traditions. Such phenomena can be explained as a challenge to the purism movement in literature and an attempt to bring the standard and real-world language usage closer together.

\subsubsection{Texts produced by mass-media sources}

The specific nature of mass-media language is that it is used to describe all manner of topics in a very short amount of time. The news that appears today in any mass-media channel in general comes from another centralized source of information. This means that most news and information in Udmurt mass media is quickly translated from Russian, and this naturally brings with it lexical loans and leads to the imposition of cultural clichés, calques, etc. In this case, even professionals with a lot of experience with the language are unable to avoid such influences. At the same time, the editorial boards of mass-media channels may have agreed on their own strategies, e.g. to use Russian or Udmurt names for days and months. If newspapers use too many neologisms and udmurtized expressions, they are criticized by their readership, because the texts become difficult to understand. 
Example (8) presents an extract from a news text, namely from the newspaper Udmurt Duńne, and it is written by a professional journalist.

$\begin{array}{rlllll}\text { (8) } \begin{array}{l}\text { udmurt } \\ \text { Udmurt }\end{array} & \text { kun } & \text { univerśifet }- \text { iś } & \text { iskusstvo-ja } & \text { no } & \text { dizajn-ja } \\ \text { state } & \text { university-ELA } & \text { art-ADV } & \text { and } & \text { design-ADV }\end{array}$

institut-len muźej-a-z uśtiśk-i-z udmurt respublika-iś

institute-GEN museum-INE-3SG open-1PRT-3SG Udmurt republic-ELA

dano užaś-len, suredaś-len vjačeslav mihajlov-len

honoured worker-GEN painter-GEN Vjaćeslav Mihailov-GEN

aร̌s̆iton-ez, 55 ar tirm-on-ez-li siźi-sa.

exhibition-3SG 55 year be.fulfilled-PRTC-3SG-DAT devote-GER

'In the museum of the Institute of Arts and Design of the Udmurt

State University, an exhibition of the Honoured Art Worker of the

Udmurt Republic, the artist Vjaćeslav Mihailov, was opened to

honour his 55th birthday.' (Udmurt Duńne, № 182, 5.12.2006: 4)

Example (8) is typical of the newspaper style: there are many titles of organizations, events and people. Most of these words are borrowed from Russian (e.g. univerśitét 'university', iskusstvo 'arts', etc.). However, some neologisms well known to readers appear as well, cf. kun 'state', ažžiton 'exhibition' and in the same newspaper (Udmurt Duńne) the word respublika can also be encoded as el'kun. Russian semantic clichés are also typical, cf. Udmurt dano užaś and Russian zaslužennij rabotńik 'Honoured Worker'. The morphosyntax of constructions that are used to code titles is Udmurt, but in the standard style, they appear with categories unusual for dialect style. For example, in nominal phrases where the dependent component expresses a purpose (e.g. iskusstvo-ja no dizajnja inst'itut 'the Institute of Arts and Design'), the dependent is marked by the adverbial $j a$. An adverbial can join nouns also in dialects, but this happens when a noun functions as an adverbial modifier, e.g. kuar tel-ja košk-i-z [leaf wind-ADV go.away-1PRT-3sG] 'A leaf blew around in the wind'. Furthermore, in this style the genitive typically joins an inanimate possessor or non-prototypical possessor, while in vernaculars it tends to mark mostly a prototypical possessor - an animate entity. Nonetheless, the new functions of the adverbial and genitive have also spread through the speech of local community members. 


\subsubsection{Spoken language approximated to standard language}

The standard language can function also in spoken form, e.g. lectures in the university and schools, public presentations and speeches, television and radio programs. It is important to note that prepared and non-prepared (non-prewritten) discourse will differ linguistically. For example, in television and radio, it is possible to observe situations when a program presenter begins by smoothly retelling a prepared text using Udmurt terms and complicated constructions. However, as soon as he or she moves on to a spontaneous discussion, the presenter's language immediately becomes irregular and is marked by pauses to search for Udmurt equivalents (neologisms that are used more rarely are difficult to remember, while in written style it is always possible to refer to dictionaries). This results in the reformulation of expressions, correction of word endings, etc. Speakers do not have enough time to think over the expressions and recall Udmurt variants, so as a result, Russian words come together with Udmurt neologisms and frequent code switching is a typical property of this style. In situations of spontaneous speech, there is also a high probability of local or dialect vernacular interference. However, a speaker still endeavors to approximate the standard language in his or her speech and prefers to use standard patterns and neologisms if he or she is able to reproduce them.

Example (9) comes from the transcript of a television program.

(9) a. pići purga joros-iś pugaćovo ćerkogurt-in in intijaśk-em Pići.Purga district-ela Pugaćovo central.village-INE situate-PRTC ožgar čast-iśs śu kikk-eti arśenal-in tilpu porom-i-z. military unit-ELA hundred two-ORD arsenal-INE fire flare.up-1PRT-3SG pugačovo-iśs no kotir-iśtí-z daskik gurt-jos-in kiź Pugaćovo-ELA and around-ELA-3SG twelve village-PL-INE twenty tamis śurs uliś-jos evakuirovat kar-emin val. eight thousand inhabitant-PL evacuate.INF do-PRTC.PSV AUX.1PRT požar-ez vormini lu-i-z kesnunal-e gine. fire-ACC win.INF be.able-1PRT-3Sg Saturday-ILL only 'The 102nd arsenal of the military unit situated in the central village of Pugaćovo in Pići Purga region has caught fire. 28,000 inhabitants of Pugaćovo and twelve neighbouring villages were evacuated. The fire was extinguished only on Saturday'. 


\section{b. mon todi-śko, ti-lad čukaźe ekzamen-di lu-o-z SG know-PRS.1SG 2PL-DAT tomorrow exam-2PL be-FUT-3SG obšśsestvoznańije predmet-ja. kin-jos sdatt-o, daś-a? social.science subject-ADV who-PL take.exam-PRS.3PL ready-INTR možet, soos šumpot-o, što ber-ges sdattini kule? maybe they be.happy-PRS.3PL CONJ late-CMP take.exam.INF need 'I know, tomorrow you will have an exam on the subject of social sciences. Who will take the exam, are they prepared? Maybe they are happy that they have to take it later?' (Moja Udmurtia: 9.6.2011)}

In the beginning of (9a), the presenter (middle-age woman, a professional journalist who has graduated from the faculty of Udmurt philology) recites a prewritten text and uses the typical udmurtized words underlined in the example, which in vernacular style would appear in Russian instead. She also expresses all compound numerals and conjunctions in Udmurt, but in colloquial style, these often appear in Russian. In this type of speech, only terms without Udmurt equivalents remain in Russian, cf. ćast' 'unit', arśenal 'arsenal' and evakuirovat' karini 'to evacuate'. Interestingly, in the beginning the notion fire is coded using the Udmurt variant tilpu and later with Russian loan požar. The style of the presenter changes when she carries on a free dialog in (9b) with guests on the program. For instance, she uses the Russian conjunction što and the word možet 'maybe'. This is not permitted in standard style and does not appear in her prewritten speech in (9a). For example, in (9a) she uses the Udmurt variant to say and: pugaćovoiś no kotiriśtiz daskik gurtjosin 'of Pugaćovo and twelve neighboring villages'. Furthermore, in (9a), when she borrows Russian verbs, she uses a construction with karini 'to do', cf. evakuirovat karini 'to evacuate'. This construction is characteristic of the standard language. However, in ( $9 b$ ) she unconsciously applies a construction with the marker -tini, cf. (ekzamen) sdattini 'to take (an exam)'. The latter construction is typical of Middle dialects and is considered vernacular style. Nevertheless, in the conversation following (9b) the presenter consciously continues to express numerals in Udmurt and uses constructions typical of the standard language, cf. patterns with an adverbial ekzamen obšśstvoznańije predmet-ja 'a social sciences exam', etc. 


\section{Conclusions}

The present paper is a general survey of the main varieties of the modern language as they exist among and are used by the Udmurts. In the descriptive linguistic literature produced so far, as a rule, one may find only observations on "high" language, corresponding to the literary form, or only pure dialect examples provided by old people, which are considered a spoken or vernacular form. The present study, however, demonstrates that these language varieties obtain a number of additional linguistic features in real-world usage. In particular, younger speakers of dialect groups may not display some typical dialect features, but may use standard forms and replace dialect forms with Russian loans. Furthermore, when people from different dialect areas with proficiency in the standard variety communicate with each other, they may use a mixed variety containing features of their own dialect and the other dialect, as well as standard forms and many Russian loans. Finally, the "high" or literary style may have an artificial character and exist only in written form. However, even the quality of carefully written texts may vary according to the writer's skills and knowledge of the language. It may happen that all words in an expression are in Udmurt, but the means of combining them are unnatural. As soon as a person wants to reproduce literary language in his or her speech, he or she has to exert a great deal of mental effort. Otherwise, in less controlled speech, a wide variety of dialect forms (which are not accepted as standard forms) and Russian loans may appear.

This kind of linguistic specificity is conditioned by the sociocultural environment of the speakers - the Udmurts are a minority surrounded by a dominating language and have a fairly young literary tradition. Changing the speakers' situation may improve language use and language development. One of the main ideas in the field of language revitalization is the investigation of social language styles and the use of those styles. It is evident that, in order to develop the language and adapt it to the modern environment, it is not enough to invent new word combinations (which is the main trend in the language development strategy at the moment), but new linguistic discourse structures should be adopted as well.

Svetlana Edygarova

University of Helsinki <svetlana.jedygarova@helsinki.fi> 


\section{Abbreviations}

$\begin{array}{llll}\text { ABL } & \text { ablative } & \text { GEN } & \text { genitive } \\ \text { ABS abessive } & \text { GER gerund } \\ \text { ADV adverbial } & \text { INTR interrogative } \\ \text { AUX auxiliary } & \text { ORD ordinal number } \\ \text { CONJ conjunction } & \text { PL } & \text { plural } \\ \text { CMP comparative } & \text { PRL prolative } \\ \text { DAT dative } & \text { PRTC participle } \\ \text { DET determinative } & \text { PSP postposition } \\ \text { EX existensial verb } & \text { PSV passive } \\ \text { FUT future } & \end{array}$

\section{Example sources}

Invožo, magazine for youth

Moja Udmurtia, TV and radio channel

Udmurt Duńne, regional newspaper

Fieldwork data (March 2011)

\section{References}

Bjulleteń 1998 = Бюллетень № 1. Удмурт кылын нимкылъёсъя но шонер гожъяськонъя элькун ӧри. 1-тӥ бичет. Ижкар.

- 2008 = Бюллетень № 2. Удмурт кылын нимкылбёсъя но шонер гожъяськонбя элькун ӧри. 2-тӥ бичет. Ижкар.

NASIBUĹĹIN 2009 = Р. Ш. Насибуллин (сост.): Диалектологический атлас удмуртского языка. Вып. 1. Ижевск.

ECKert, Penelope \& John R. Rickford 2001: Style and sociolinguistic variation. Cambridge.

GAL, SUSAN 1979: Language shift: Social determinants of linguistic change in bilingual Austria. New York.

Hoffmann, Charlotte 1991: An introduction to bilingualism. London - New York.

Kel'makov, Valentin \& Sirkka SaARInen 1994: Udmurtin murteet. Turun yliopiston suomalaisen ja yleisen kielitieteen laitoksen julkaisuja 47. Iževsk - Turku.

Kel'makov, Valentin \& SARA HÄNNIKÄInen 1999: Udmurtin kielioppia ja harjoituksia. Apuneuvoja suomalais-ugrilaisten kielten opintoja varten XIV. Helsinki: SuomalaisUgrilainen Seura.

KREINDLER, IsABELLE 1989: Soviet language planning since 1953. - M. Kirkwood (ed.): Language Planning in the Soviet Union. London. 46-63.

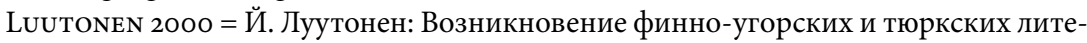
ратурных языков Поволжья и вопрос о литературном языке в начале XX в. Этническая мобилизация во внутренней периферии: Волго-Камский регион начала ХХ в. Ижевск. 21-42. 


\section{Svetlana Edygarova}

MaAs, Utz 2009: Orality versus literacy as a dimension of complexity. - G. Sampson, G. David, \& P. Trudgill (eds): Language complexity as an evolving variable. Oxford. 164-177.

Milroy, Lesley 1987: Language and social networks. Oxford.

Myers-Scotton, CARol 2006: Multiple voices: an introduction to bilingualism. Oxford.

Patrick, Peter L. 2011: Notes on the sociolinguistics of style(-shifting).

$<\mathrm{http} / / /$ courses.essex.ac.uk/lg/lg232/stylenotes.html>

SAmpson, Geoffrey 2009: A linguistic axiom challenged. - G. Sampson, G. David \& P. Trudgill (eds): Language complexity as an evolving variable. Oxford. 1-18.

Sarhimaa, Anneli 1999: Syntactic transfer, contact-induced change, and the evolution of bilingual mixed codes. Studia Fennica Linguistica 9. Helsinki: Suomalaisen Kirjallisuuden Seura.

- 2009: Social network theory as a framework for studying minor Finnic languages with special reference to Karelian. - Jussi Ylikoski (ed.): The Quasquicentennial of the Finno-Ugrian Society. Mémoires de la Société Finno-Ougrienne 258. Helsinki: Société Finno-Ougrienne. 161-190.

VAHRUŠEV 1975 = В. М. Вахрушев: К вопросу о формировании и развитии удмуртского литературного языка. - Вопросы удмуртского языкознания. Вып. 3. Ижевск. 42-55.

Wolfram, Walt \& Natalie Schilling-Estes 1998: American English: dialects and variation. Oxford. 